\title{
Памяти Виталия Александровича Лихошвая: уроки, беседы и воспоминания
}

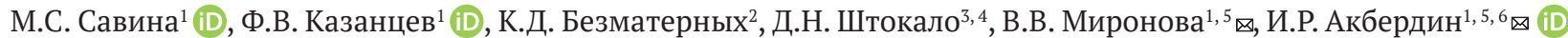

Для цитирования: Савина М.С., Казанцев Ф.В., Безматерных К.Д., Штокало Д.Н., Миронова В.В., Акбердин И.Р. Памяти Виталия Александровича Лихошвая: уроки, беседы и воспоминания. Письма в Вавиловский журнал генетики и селекции. 2020;6(4):193-198. DOI 10.18699/ Letters2020-6-25

\section{In memory of Vitaly A. Likhoshvai: lessons, conversations and memories}

\author{
M.S. Savina ${ }^{1}(\mathbb{D})$, F.V. Kazantsev ${ }^{1}(\mathbb{D})$, K.D. Bezmaternykh² ${ }^{2}$ D.N. Shtokalo ${ }^{3,4}$, V.V. Mironova ${ }^{1,5} \bowtie$, I.R. Akberdin ${ }^{1,5,6} \bowtie(\mathbb{D}$
}

For citation: Savina M.S., Kazantsev F.V., Bezmaternykh K.D., Shtokalo D.N., Mironova V.V., Akberdin I.R. In memory of Vitaly A. Likhoshvai: lessons, conversations and memories. Pisma v Vavilovskii Zhurnal Genetiki i Selektsii = Letters to Vavilov Journal of Genetics and Breeding. 2020;6(4):193-198. DOI 10.18699/Letters2020-6-25 (in Russian)

10 февраля 2019 года не стало ведущего сотрудника Института цитологии и генетики СО РАН доктора биологических наук Виталия Александровича Лихошвая - выдающегося ученого в области математического моделирования биологических систем.

Научные идеи, гипотезы Виталия Александровича о структурно-функциональной организации и динамике функционирования молекулярно-генетических систем, разработанные им и в сотрудничестве с коллегами математические модели (Ратушный, 2020) не только улучшили наше понимание причинно-следственных связей между структурой генных сетей и фенотипическими признаками живых систем, функционирующих под их управлением, но и внесли неоценимый вклад в развитие школы математического моделирования биологических систем в Новосибирском Академгородке. Помимо созданного лекционного курса «Математические основы системной биологии: моделирование молекулярно-генетических систем» на кафедре информационной биологии факультета естественных наук Новосибирского государственного университета под руководством Виталия Александровича успешно защищались как теоретические, так и экспериментально-теоретические дипломные работы, кандидатские диссертации, в каждой из которых чувствовались глубокая проработка проблемы и математическая изюминка, появлявшаяся только после длительных и увлекательных научно-образовательных бесед с интересным, неординарным, а иногда и горячо спорящим собеседником, учителем и наставником Виталием Александровичем Лихошваем. Нам, ученикам Виталия Александровича, кому посчастливилось работать под его руководством и совместно с ним в разные годы жизни, хотелось бы вспомнить уникальные моменты этих бесед и научных уроков, определившие ключевые принципы, которыми должен руководствоваться математический биолог при изучении загадочного мира живых систем.

Федеральный исследовательский центр Институт цитологии и генетики Сибирского отделения Российской академии наук, Новосибирск, Россия

2 ООО «Дойче Банк», Москва, Россия

${ }^{3}$ Институт систем информатики им. А.П. Ершова Сибирского отделения Российской академии наук, Новосибирск, Россия

${ }^{4}$ ООО «АкадемДжин», Новосибирск, Россия

${ }^{5}$ Новосибирский национальный исследовательский государственный университет, Новосибирск, Россия

${ }^{6} \mathrm{OOO}$ «Биософт.ру», Новосибирск, Россия

Institute of Cytology and Genetics of Siberian Branch of the Russian Academy of Sciences, Novosibirsk, Russia

2 Deutsche Bank, Moscow, Russia

${ }^{3}$ A.P. Ershov Institute of Informatics Systems of Siberian Branch of the Russian Academy of Sciences, Novosibirsk, Russia

${ }^{4}$ AcademGene LLC, Novosibirsk, Russia

${ }^{5}$ Novosibirsk State University, Novosibirsk, Russia

Biosoft.ru LLC, Novosibirsk, Russia

凶kviki@bionet.nsc.ru, akberdinir@gmail.com

(ㄷ) Савина М.С., Казанцев Ф.В., Безматерных К.Д., Штокало Д.Н., Миронова В.В., Акбердин И.Р., 2020 


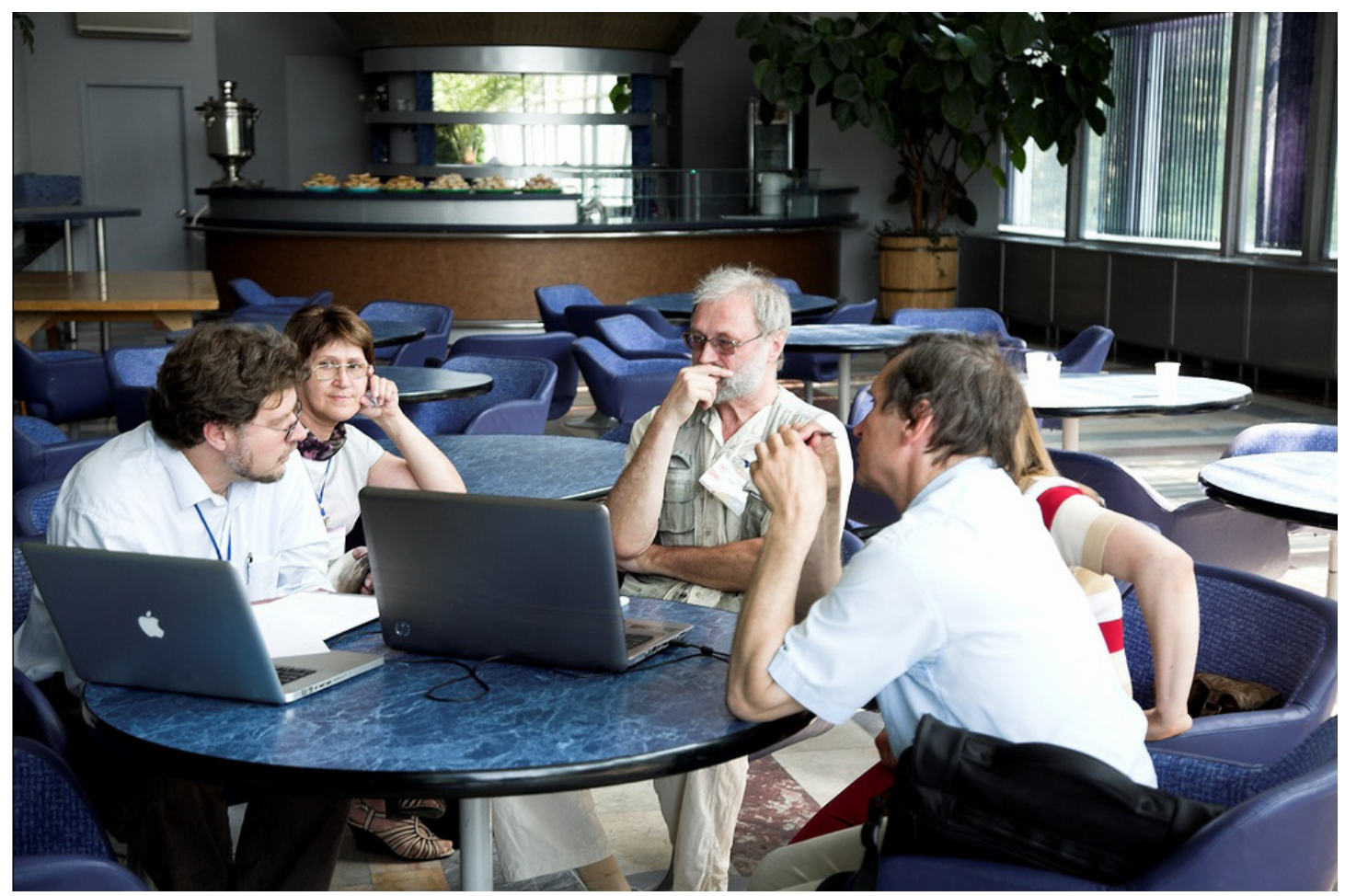

Обсуждение научных задач с проф. Э.Д. Мелснессом (Калифорнийский университет в Ирвайне, США), Т.М. Хлебодаровой (ИЦиГ СО РАН), И.И. Матвеевой, Г.В. Демиденко (ИМ СО РАН) на международной конференции BGRS/SB-2012. Новосибирск. Академгородок. Дом ученых СО РАН, 2012

\section{Беседы об универсальном'}

Виталий Александрович Лихошвай был моим научным руководителем во время прохождения преддипломной практики в Новосибирском государственном университете. Несмотря на то что основную часть моей практики фактически курировала его ученица, Миронова Виктория Владимировна, Виталий Александрович многому меня научил. При затруднениях с разработкой математической модели или анализом результатов моделирования одна только беседа с Виталием Александровичем порождала новый виток размышлений и в конечном итоге приводила к продвижению в исследовании. Этот человек не просто обладал знаниями и навыками, необходимыми для математического моделирования биологических процессов, но тонко чувствовал механизмы, лежащие в их основе, а главное - задавал правильные вопросы. Виталий Александрович умел выделять главное, не углубляясь в частности, что позволяло ему находить универсальные механизмы, лежащие в основе многих биологических процессов на разных уровнях организации живой материи. Разработанная им методика моделирования молекулярно-генетических систем путем сборки модели из отдельных модулей, описывающих элементарные события, универсальна и применима к любому биологическому процессу в любом организме на любом уровне организации: от молекулярного и клеточного до тканевого и организменного. Подходы к описанию взаимодействия элементов молекулярно-генетических систем с помощью функций Хилла (Likhoshvai, Ratushny, 2007), разработанные

\footnotetext{
${ }^{1}$ Автор раздела Мария Савина
}

Виталием Александровичем, его ученики до сих пор активно применяют в Институте цитологии и генетики СО РАН для моделирования различных аспектов жизнедеятельности живых организмов (Mironova et al., 2013; Hong et al., 2017; Akberdin et al., 2018; Kazantsev et al., 2018; Akberdin et al., 2020; Canher et al., 2020; Savina, Mironova, 2020).

\section{Атмосфера научного творчества 2}

С Виталием Александровичем я познакомился в 2001 году будучи студентом Высшего колледжа информатики Новосибирского государственного университета первого набора по непонятной тогда специальности «Биоинформатика». В это время нужно было выбрать научных руководителей. Наша встреча произошла случайно. С назначенным мне куратором встреча сорвалась, и я за компанию с одногруппниками пошел к их руководителю. Так я попал в комнату, в которой находились Виталий Александрович Лихошвай, Александр Владимирович Ратушный и Юрий Георгиевич Матушкин. Нас, тогда еще совсем юных студентов, встретили тепло: мы рассказали, что уже умеем и чем бы хотели заниматься. С тех пор я стал частым гостем в этом кабинете, а руководителем на время студенчества стал Александр Владимирович. Атмосфера взаимного уважения и поддержки подвигла меня продолжить работу уже студентом университета и далее пойти к Виталию Александровичу в аспирантуру.

Мои уже окрепшие технические навыки были применены в автоматизации проверки математических моделей

\footnotetext{
${ }^{2}$ Автор раздела Федор Казанцев.
} 


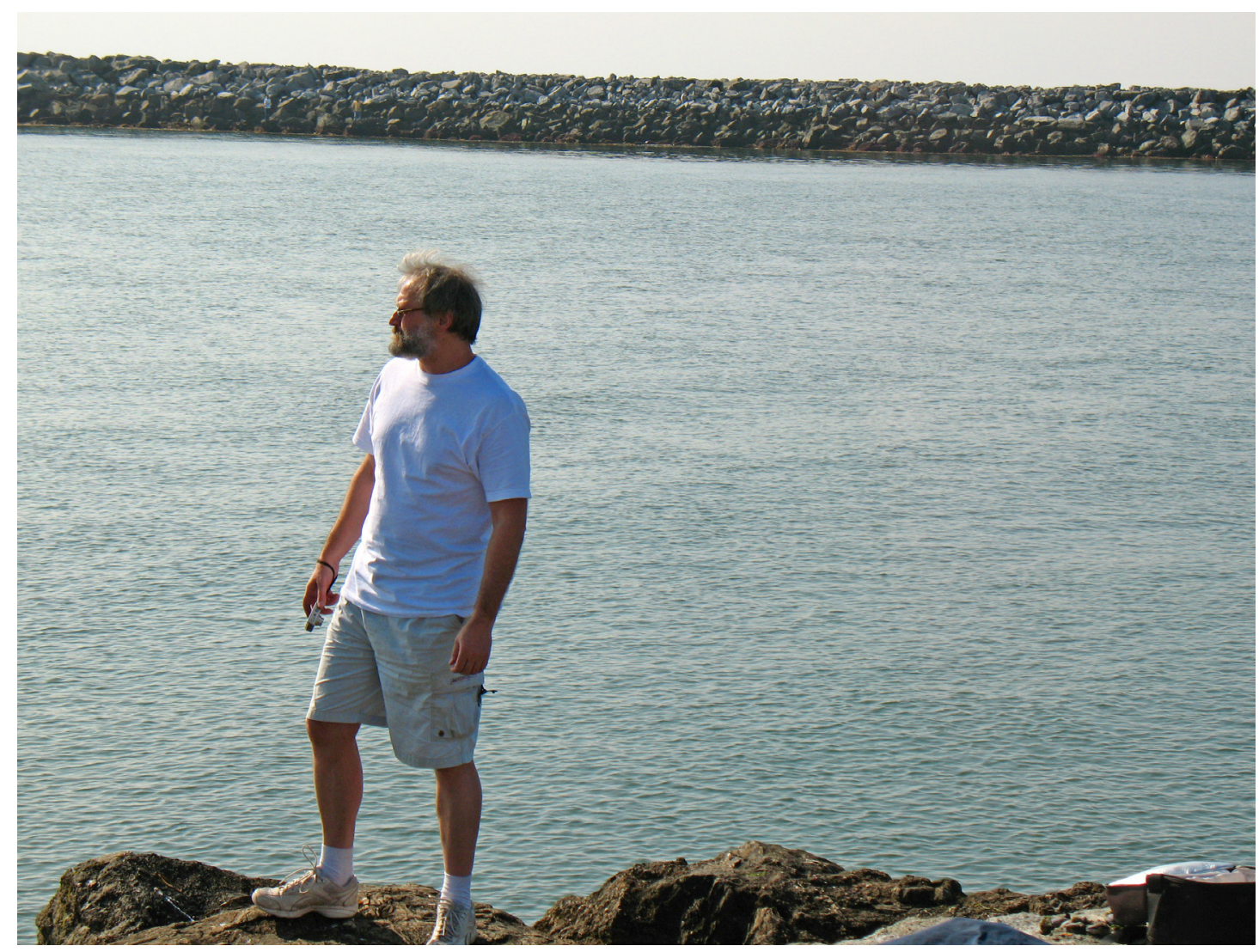

Возле морской лаборатории Уильяма Дж. Керкхоффа (Калифорнийский технологический институт) во время визита в рамках научного сотрудничества с лабораторией проф. Э.Д. Мелснесса (Калифорнийский университет в Ирвайне, США), 2007

в развиваемом Виталием Александровичем формализме обобщенного химико-кинетического метода моделирования (Бажан, 2020; Likhoshvai et al., 2000). Серия разработанных инструментов вошла в дипломную работу. Затем развитие этих идей, подходов и их использование в конкретных задачах перетекло в диссертацию. Так благодаря Виталию Александровичу я познакомился с большим количеством прекрасных людей - научных сотрудников, аспирантов и студентов. Одним я облегчил жизнь в использовании обобщенного химико-кинетического метода моделирования, с другими завязались теплые дружеские и рабочие отношения, которые вылились в серию интересных совместных работ (Mironova et al., 2012; Novoselova et al., 2013; Kazantsev et al., 2018).

\section{Уроки моделирования для физика ${ }^{3}$}

Мне повезло попасть в аспирантуру в лабораторию теоретической генетики Института цитологии и генетики СО РАН, где кроме прочих работали Юрий Георгиевич Матушкин и Виталий Александрович Лихошвай. Моим формальным руководителем был Юрий Георгиевич, а Виталий Александрович наблюдал за моими попытками построения математических моделей генетических систем и помогал изучать их свойства.

Специфика моей работы в лаборатории сводилась к задаче оптимального управления математическими моделя-

\footnotetext{
${ }^{3}$ Автор раздела Кирилл Безматерных.
}

ми генетических систем, с которой нам помогали математики из Института теоретической и прикладной механики СО РАН: мы применяли их опыт и наработки в космической, авиационной и других сферах на математических моделях живых систем. Однако большую часть времени я все равно посвящал разработке моделей и налаживанию их работы (адаптации к известным экспериментальным данным). С Виталием Александровичем мы работали над разными математическими моделями, включая модель внутриклеточного подавления развития вируса гепатита С в клетке, внутриклеточную модель циркадного ритма млекопитающих и математическую модель распространения туберкулеза (Bezmaternykh et al., 2006; Mishchenko et al., 2007). На каждом этапе исследовательской работы Виталий Александрович требовал от нас знания объекта моделирования на уровне экспертов-биологов. Во время работы по созданию новой математической модели требовалось прочитать несколько сотен научных публикаций - от обзорных до узкоспециализированных, систематизировать все данные об объекте моделирования и выбрать наиболее значимые. Даже после этого фильтра оставалось очень большое количество публикаций по экспериментальной биологии. Прочитать и осмыслить их все было, наверное, самым главным испытанием для меня во время работы в лаборатории.

Виталий Александрович посвятил не одну научную публикацию обобщенным функциям Хилла и их применению 
в математическом моделировании генетических систем (Likhoshvai, Ratushny, 2007). Если честно, вначале это казалось мне какой-то магией - как легко метод позволял описывать зависимости концентраций веществ, участвующих в ферментативных реакциях. Помимо возможности обобщенных функций Хилла естественным образом описывать внутриклеточные реакции в условиях квазиравновесия меня поражала их универсальность: несмотря на недостаток знаний и данных о механизме реакции, скорости ее протекания, с помощью обобщенных функций Хилла все равно можно было построить математическую модель без лишнего количества свободных переменных, с одной стороны, и с другой - согласующуюся с имеющимися экспериментальными данными.

Отдельно стоит отметить процесс написания статей с Виталием Александровичем. Он заставлял меня переписывать текст несколько раз - пока не получится что-то сносное. «Меньше воды» или «Это все вода», - говорил он, проверяя мой очередной неудачный вариант. В мучениях, но постепенно и последовательно начинало что-то получаться, и в конце концов выкристаллизовывался текст, который можно было отправить в научный журнал или сборник тезисов конференции.

\section{Красота - критерий истины ${ }^{4}$}

Интерес к математической биологии разгорелся во мне именно благодаря Виталию Александровичу. Обучаясь на третьем курсе механико-математического факультета НГу (2004), я жаждал применения знаний математики к чемунибудь, к решению какой-нибудь «великой» проблемы. В это время Виталий Александрович активно работал с математиками Станиславом Ивановичем Фадеевым, Геннадием Владимировичем Демиденко, Владимиром Петровичем Голубятниковым. Как биологу и математику, Виталию Александровичу удавалось добиться невероятно красивых математических постановок биологических задач (Лихошвай и др., 2003, 2004). Проиллюстрированные примерами (Виталий Александрович был великолепный рассказчик) задачи выглядели многослойно и привлекали многих ученых: от амбициозных студентов до заслуженных профессоров. С каждой доказанной теоремой, численно проверенной гипотезой все больше математиков интересовалось «задачами Лихошвая» (Golubyatnikov, Minushkina, 2020). Виталий Александрович любил говорить, что «красота - критерий истины» и что «в каждой науке столько истины, сколько в ней математики». Успехи в решении сформулированных Виталием Александровичем биологических задач позволяли математикам чувствовать, что они помогают находить истину и красоту, что они причастны к большому делу. И это действительно так - я часто вижу за происходящими процессами в биологии, экономике и политике математические модели, которые мы изучали с Виталием Александровичем. Это позволяет ориентироваться и до какой-то степени просчитывать поведение живых систем. Многие задачи еще ждут своего решения.

\footnotetext{
${ }^{4}$ Автор раздела Дмитрий Штокало
}

\section{Уроки моделирования для биолога 5}

«Образовываться надо, глубже разбираться в математической теории», - раз за разом повторял мне Виталий Александрович. Мне, как биологу, это было не просто. Но как же я благодарна ему за эти советы и как сожалею, что не всегда их слушала...

К Виталию Александровичу на втором году обучения в аспирантуре меня привела Надежда Анатольевна Омельянчук. Основная тема моей научной работы застопорилась, и я, начитавшись научных статей, нашла кое-что интересное: гипотезу, которая бы объяснила механизм регенерации стволовых клеток растений. Проблема в том, что мне было очень сложно ее кому-то объяснить. Гипотеза подразумевала пространственно-временные динамические изменения, которые прекрасно согласовались у меня в голове, но не на бумаге и словах. Послушав нас с Надеждой Анатольевной, Виталий Александрович заключил: «Надо срочно делать математическую модель». Так он открыл для меня огромную область науки, которая оказалась именно тем, чем я всегда хотела заниматься, просто не знала об этом.

Виталий Александрович дал мне первую версию математической модели, состоящую из набора файлов с длинными именами и непонятными расширениями, написанную на языке, который он сам придумал. Справочной информации или руководства пользователя поначалу не было. Помню эти ощущения шпиона-дешифровщика, разбирающегося в чужом коде. На самом деле это был бесценный опыт. Он помог почувствовать, что такое математическое моделирование и отбил страх перед использованием нестандартных решений. Все решения были нестандартными.

Потребовалось почти пять лет, чтобы опубликовать наше нестандартное решение по исследованию поддержания ниши стволовых клеток в корне в зарубежном журнале (Mironova et al., 2010). Было сложно: к моменту, когда мы были готовы опубликовать первый вариант статьи, в Nature вышла работа, в которой исследовалась та же самая проблема с помощью методов математического моделирования. Она была о другом, но это уже никого не интересовало - работа в Nature предлагала простое (но не полное) решение. Еще три года ушло на то, чтобы убедить научное сообщество, что наше решение лучше и богаче. Действительно, эта работа стала базисом для многих последующих работ (Mironova et al., 2012; Hong et al., 2017; Canher et al., 2020), которых бы не было, если бы Виталий Александрович не принял меня в ученицы.

На защите моей диссертации в 2010 году директор нашего Института Н.А. Колчанов несколько раз назвал меня Викторией Витальевной (мое отчество Владимировна). Забавная оговорка, подумала я: Виталий Александрович действительно был моим отцом в науке.

\section{Погружение в мир моделирования ${ }^{6}$}

Виталий Александрович Лихошвай на протяжении всего времени нашего знакомства и совместной работы представлял для меня ярчайший пример настоящего ученого, чрезвычайно преданного «царице-науке», как часто он

\footnotetext{
${ }^{5}$ Автор раздела Виктория Миронова.

${ }^{6}$ Автор раздела Илья Акбердин.
} 
сам замечал, и скрупулезно, детально разбирающегося в сути изучаемой проблемы или явления. Это понимание сложилось у меня с самого первого, скажем так, заочного знакомства с Виталием Александровичем. После защиты дипломной работы в 2005 году на кафедре цитологии и генетики факультета естественных наук Новосибирского государственного университета я начал определяться с новой темой исследования в рамках аспирантуры и знакомиться с текущими научными работами в лабораториях Института цитологии и генетики СО РАН. По совету Павла Михайловича Бородина, заведующего лабораторией рекомбинационного и сегрегационного анализа, в которой я выполнял дипломную работу, я встретился с руководителем лаборатории теоретической генетики профессором Николаем Александровичем Колчановым. После продолжительной беседы о моих навыках и, главное, дальнейших планах и научных интересах Николай Александрович сделал неожиданное предложение: «Знаете, у нас в лаборатории есть неординарный ученый, который даже во сне формулирует математические теоремы, имеющие существенное значение для понимания механизмов функционирования живых систем. Думаю, вам стоит встретиться с Лихошваем Виталием Александровичем». Через некоторое время я подробно узнал о сути этих совместных работ Виталия Александровича с коллегами из Института математики СО РАН, которые математически обосновали предельный переход от моделей генных сетей, явно учитывающих на стадии промежуточного синтеза конечных продуктов, к моделям с запаздывающими аргументами (Лихошвай и др., 2003, 2004; Демиденко, Лихошвай, 2005; Фадеев и др., 2005; Демиденко и др., 2006). С этого неожиданного на тот момент для меня факта и началась история моего знакомства с Виталием Александровичем. Наша первая очная встреча с Виталием Александровичем состоялась через несколько дней в кабинете на третьем этаже Института цитологии и генетики, где помимо него работали Александр Владимирович Ратушный и Юрий Георгиевич Матушкин. Виталий Александрович внимательно и с интересом выслушал результаты моей дипломной работы и с еще большим энтузиазмом, увлекательно рассказал об области своих исследований в биологии, предложив ознакомиться с несколькими публикациями по совершенно новой для меня тематике: теории генных сетей и применению методов математического моделирования в изучении механизмов и динамике функционирования молекулярно-генетических систем. Несколькими неделями позже мы встретились с Виталием Александровичем, чтобы обсудить, что мне удалось понять из этих работ, и попытаться сформулировать тему моей научной работы. В результате нашей беседы Виталий Александрович предложил приступить к математическому моделированию кинетики ферментативных реакций прокариотических организмов в «настоящем бою» - в то время в лаборатории заканчивался совместный проект с японской биотехнологической компанией «Аджиномото», в рамках которого должны были быть созданы базы математических моделей и кинетических данных о более 300 ферментативных реакциях, составляющих основу метаболизма E. coli. В процессе выполнения этого проекта сформировался сплоченный коллектив как опытных специалистов, научных сотрудников Института, так и молодых студентов, аспирантов, только начинающих научную карьеру (Хлебодарова, 2020). С этого и началось мое погружение в мир математического моделирования живых систем под руководством Виталия Александровича.

Несмотря на то что моя диссертационная работа была посвящена теоретическому исследованию механизмов регуляции развития меристемы побега в эмбриогенезе растений, мы периодически с Виталием Александровичем проводили не один час в обсуждениях подходов создания «электронной клетки» - модельного прототипа живой клетки - одной из актуальных областей развития системной биологии и в настоящее время. Жаркие дискуссии по этой проблеме не ограничивались стенами Института - мы продолжали говорить об этом и за обедом в столовой, и в поездках на конференции, и даже во время игры в большой теннис, интерес к которому тоже привил Виталий Александрович. В процессе одной из таких бесед Виталий Александрович предложил написать обзорную статью по этой проблеме на русском языке, чтобы сформулировать собственное видение постановки задачи, ее важнейший фундаментальный характер и, конечно, прикладное значение. Помню, как начало работы над совместной статьей было очень напряженным и требовало полного погружения в проблему как в биологических, так и математических аспектах. Но настойчивость, тонкое чувство юмора и огонек в глазах Виталия Александровича от обсуждений разделов статьи всегда придавали уверенность в успешном исходе работы и стимулировали двигаться в этом вопросе. На протяжении нескольких месяцев упорной работы над публикацией с Виталием Александровичем и Тамарой Михайловной Хлебодаровой удалось сформулировать основные, с нашей точки зрения, проблемы создания «электронной клетки» и подходы к ее решению, в том числе разработанные и развиваемые в Институте цитологии и генетики СО РАН (Акбердин и др., 2013).

На одном из семинаров нашей группы моделирования молекулярно-генетических систем Виталий Александрович так охарактеризовал свой стиль научного руководства: «Я отношусь к тем руководителям, которые бросают человека и заставляют его плыть. Если не можешь плыть, то утонешь». Я, как, думаю, и многие ученики Виталия Александровича, до сих пор вспоминаю с теплом и огромной благодарностью эти удивительные «заплывы» и погружения в теоретические основы исследования живых систем с помощью математического моделирования.

\section{Список литературы / References}

Акбердин И.Р., Казанцев Ф.В., Ермак Т.В., Тимонов В.С., Хлебодарова Т.М., Лихошвай В.А. «Электронная клетка»: проблемы и перспективы. Математическая биология и биоинформатика. 2013;8(1):287-307.

[Akberdin I.R., Kazantsev F.V., Ermak T.V., Timonov V.S., Khlebodarova T.M., Likhoshvai V.A. "Electronic cell”: challenges and prospects. Math. Biol. Bioinform. 2013;8(1):287-307. (in Russian)]

Бажан С.И. Виталий Александрович Лихошвай: первые шаги в науке. Письма в Вавиловский журнал генетики и селекции. 2020;6(4):164167. DOI 10.18699/Letters2020-6-20.

[Bazhan S.I. Vitaly A. Likhoshvai: the first steps in science. Pisma $\checkmark$ Vavilovskii Zhurnal Genetiki $i$ Selektsii $=$ Letters to Vavilov Journal 
of Genetics and Breeding. 2020;6(4):164-167. DOI 10.18699/Letters2020-6-20.

Демиденко Г.В., Лихошвай В.А. О дифференциальных уравнениях с запаздывающим аргументом. Сибирский математический журнал. 2005;46(3):538-552.

[Demidenko G.V., Likhoshvai V.A. On differential equations with retarded argument. Siberian Math. J. 2005;46(3):417-430]

Демиденко Г.В., Лихошвай В.А., Котова Т.В., Хропова Ю.Е. Об одном классе систем дифференциальных уравнений с запаздывающим аргументом. Сибирский математический журнал. 2006;47(16):58-68. [Demidenko G.V., Likhoshvai V.A., Kotova T.V., Khropova Yu. E. On one class of systems of differential equations and on retarded equations. Siberian Math. J. 2006;47(1):45-54.]

Лихошвай В.А., Матушкин Ю.Г., Фадеев С.И. Задачи теории функци онирования генных сетей. Сибирский журнал индустриальной математики. 2003;6:64-80.

[Likhoshvai V.A., Matushkin Yu.G., Fadeev S.I. Problems in the theory of the functioning of genetic networks. Sib. Zh. Ind. Math. 2003;6:6480. (in Russian)]

Лихошвай В.А., Фадеев С.И., Демиденко Г.В., Матушкин Ю.Г. Моделирование многостадийного синтеза вещества без ветвления уравнением с запаздывающим аргументом. Сибирский журнал индустриальной математики. 2004;7(1):73-94.

[Likhoshvai V.A., Fadeev S.I., Demidenko G.V., Matushkin Yu.G. Modeling multistage synthesis without branching by a delay equation. Sib. Zh. Ind. Math. 2004;7(1):73-94. (in Russian)]

Ратушный А.В. В память о Виталии Александровиче Лихошвае, научном наставнике и учителе. Письма в Вавиловский журнал генетики и селекции. 2020;6(4):179-184. DOI 10.18699/Letters2020-6-22.

[Ratushny A.V. In memory of Vitaly A. Likhoshvai, scientific mento and teacher. Pisma v Vavilovskii Zhurnal Genetiki $i$ Selektsii $=$ Letters to Vavilov Journal of Genetics and Breeding. 2020;6(4):179-184. DOI 10.18699/Letters2020-6-22. (in Russian)]

Фадеев С.И., Лихошвай В.А., Штокало Д.Н. Исследование модели синтеза линейных биомолекул с учетом обратимости процессов. Сuбирский журнал индустриальной математики. 2005;8(3):149-162. [Fadeev S.I., Likhoshvai V.A., Shtokalo D.N. Study of a model of linear biomolecular synthesis with reversible processes. J. Appl. Industr. Math. 2007;1(2):178-189.]

Хлебодарова Т.М. О решенных и нерешенных проблемах биологии в исследованиях В.А. Лихошвая. Письма в Вавиловский журнал генетики и селекции. 2020;6(4):168-178. DOI 10.18699/Letters2020-6-21.

[Khlebodarova T.M. On solved and unresolved biology problems in research of V.A. Likhoshvai. Pisma $v$ Vavilovskii Zhurnal Genetiki $i$ Selektsii $=$ Letters to Vavilov Journal of Genetics and Breeding. 2020;6(4):168-178. DOI 10.18699/Letters2020-6-21. (in Russian)]

Akberdin I.R., Omelyanchuk N.A., Fadeev S.I., Leskova N.E., Oschepkova E.A., Kazantsev F.V., Matushkin Yu.G., Afonnikov D.A., Kolchanov N.A. Pluripotency gene network dynamics: system views from parametric analysis. PLOS One. 2018;13(3):e0194464. DOI 10.1371/ journal.pone.0194464.

Akberdin I.R., Vertyshev A., Pintus S.S., Popov D.V., Kolpakov F.A. A mathematical model linking $\mathrm{Ca}^{2+}$-dependent signaling pathway and gene expression regulation in human skeletal muscle. Math. Biol. Bioinform. 2020;15(1):20-39. DOI 10.17537/2020.15.20.

Bezmaternykh K.D., Mishchenko E.L., Ratushny A.V., Likhoshvai V.A., Khlebodarova T.M., Ivanisenko V.A. Mathematical modeling of the reproduction of the hepatitis $C$ virus replicon in cell culture. Simulation of the action of potential therapeutics. Biophysics. 2006;51(1):70-74.

Canher B., Heyman J., Savina M., Devendran A., Eekhout T., Vercauteren I., Prinsen E., Matosevich R., Xu J., Mironova V., De Veylder L. Rocks in the auxin stream: Wound-induced auxin accumulation and ERF115 expression synergistically drive stem cell regeneration. Proceedings National Academy Sciences. 2020;117(28):16667-16677.

Golubyatnikov V.P., Minushkina L.S. Combinatorics and geometry of circular gene networks models. Pisma v Vavilovskii Zhurnal Genetiki $i$ Selektsii $=$ Letters to Vavilov Journal of Genetics and Breeding. 2020;6(4):188-192. DOI 10.18699/Letters2020-6-24.

Hong J.H., Savina M., Du J., Devendran A., Ramakanth K.K., Tian X., SimW.S., Mironova V.V., Xu J. A sacrifice-for-survival mechanism protects root stem cell niche from chilling stress. Cell. 2017;170(1):102-113.

Kazantsev F., Akberdin I., Lashin S., Ree N., Timonov V., Ratushny A., Khlebodarova T., Likhoshvai V. MAMMOTH: a new database for curated mathematical models of biomolecular systems. J. Bioinform. Comput. Biol. 2018;16(1):e1740010. DOI 10.1142/S0219720017400108.

Likhoshvai V., Ratushny A. Generalized Hill function method for modeling molecular processes. J. Bioinform. Comput. Biol. 2007;5(2B):521531. DOI 10.1142/s0219720007002837.

Likhoshvai V.A., Matushkin Yu.G., Vatolin Yu.N., Bazhan S.I. A generalized chemical kinetic method for simulating complex biological systems. A computer model of $\lambda$ phage ontogenesis. Computat. Technol. 2000;5(2):87-99.

Mironova V.V., Novoselova E.S., Doroshkov A.V., Kazantsev F.V., Omelyanchuk N.A., Kochetov A.V., Mjolsness E., Likhoshvai V.A. Combined in silico/in vivo analysis of mechanisms providing for root apical meristem self-organization and maintenance. Ann. Bot. 2012;110(2):349360. DOI 10.1093/aob/mcs069.

Mironova V.V., Omelyanchuk N.A., Savina M.S., Ponomarenko P.M., Ponomarenko M.P., Likhoshvai V.A., Kolchanov N.A. How multiple auxin responsive elements may interact in plant promoters: a reverse problem solution. J. Bioinform. Comput. Biol. 2013;11(01):1340011.

Mironova V.V., Omelyanchuk N.A., Yosiphon G., Fadeev S.I., Kolchanov N.A., Mjolsness E., Likhoshvai V.A. A plausible mechanism for auxin patterning along the developing root. BMC Syst. Biol. 2010;4:98. DOI 10.1186/1752-0509-4-98.

Mishchenko E.L., Bezmaternykh K.D., Likhoshvai V.A., Ratushny A.V., Khlebodarova T.M., Sournina N.Yu., Ivanisenko V.A., Kolchanov N.A. Mathematical model for suppression of subgenomic hepatitis $C$ virus RNA replication in cell culture. J. Bioinform. Comput. Biol. 2007;5(02b):593-609.

Novoselova E.S., Mironova V.V., Omelyanchuk N.A., Kazantsev F.V., Likhoshvai V.A. Mathematical modeling of auxin transport in protoxylem and protophloem of Arabidopsis thaliana root tips. J. Bioinform. Comput. Biol. 2013;11(1):1340010. DOI 10.1142/S0219720013400106.

SavinaM.S.,MironovaV.V.PlantLayoutpipelinetomodeltissuepatterning. Vavilovskii Zhurnal Genetiki i Selektsii = Vavilov Journal of Genetics and Breeding. 2020;24(1):102-107. DOI 10.18699/VJ20.590. 